University of Maryland Francis King Carey School of Law

DigitalCommons@UM Carey Law

2013

\title{
Private-Rights Litigation and the Normative Foundations of Durable Constitutional Precedent
}

\author{
Maxwell L. Stearns \\ University of Maryland Francis King Carey School of Law, mstearns@law.umaryland.edu
}

Follow this and additional works at: https://digitalcommons.law.umaryland.edu/fac_pubs

Part of the Constitutional Law Commons

\section{Digital Commons Citation}

Christopher J. Peters, ed. Precedent in the United States Supreme Court. New York, Springer, 2013. (Ius Gentium: Comparative Perspectives on Law and Justice).

This Book Chapter is brought to you for free and open access by the Francis King Carey School of Law Faculty at DigitalCommons@UM Carey Law. It has been accepted for inclusion in Faculty Scholarship by an authorized administrator of DigitalCommons@UM Carey Law. For more information, please contact smccarty@law.umaryland.edu. 


\title{
Private-Rights Litigation and the Normative Foundations of Durable Constitutional Precedent
}

\author{
Maxwell L. Stearns*
}

\begin{abstract}
This chapter advances a simple thesis that runs counter to much public-law scholarship. Holding all else constant, the more difficult, or costly, constitutional rulings are to obtain, the more durable the resulting precedent; conversely, the easier, or cheaper, such rulings are to obtain, the less durable the resulting precedent. Most public-law scholarship implicitly rests on the opposite premise that the relative ease or difficulty of obtaining constitutional rulings should correlate positively, not negatively, with the relative importance or unimportance of the asserted right. Within a public-rights adjudicatory model, important constitutional rights justify relaxing traditional constraints on constitutional decisionmaking, including ripeness, mootness, and, most notably, standing. Conversely, within a private-rights adjudicatory model, judicial rulings, however important, are legitimated by the need to resolve actual cases or controversies presumptively arising from circumstances beyond the claimant's control.
\end{abstract}

The public-rights model produces an unintended consequence for those seeking durable constitutional precedent. To the extent that the timing of constitutional litigation is driven by the happenstance of ideological sympathies of deciding jurists, the normative justification for affording the resulting precedent durable status is compromised once those conditions change, favoring the other side. By contrast, the private-rights adjudicatory model makes constitutional precedent more costly to obtain on all sides, thereby enhancing the normative foundation for affording precedent durable status. The analysis holds important implications for several notable bodies of law, including the historical status of Brown v. Board of Education; the stare decisis analysis in the jointly authored plurality opinion in the 1992 decision, Planned Parenthood of Southeastern Pennsylvania v. Casey; and Supreme Court doctrine concerning agency deference rules.

\footnotetext{
${ }^{*}$ Professor of Law and Marbury Research Professor, University of Maryland Francis King Carey School of Law. B.A. University of Pennsylvania, J.D. University of Virginia School of Law. The author would like to thank David McAloon for his helpful research assistance.
} 


\title{
Private-Rights Litigation and the Normative Foundations of Durable Constitutional Precedent
}

\author{
Maxwell L. Stearns
}

\section{Introduction}

This chapter advances a simple thesis, albeit one that runs against the grain of much American public-law scholarship: Holding all else constant, the more difficult, or costly, a constitutional ruling is to obtain, the more valuable the resulting precedent, and conversely, the easier, or less costly, a constitutional ruling is to obtain, the less valuable the resulting president. Most public-law scholarship implicitly rests on the opposite premise that the relative ease or difficulty of obtaining a constitutional ruling should correlate positively, rather than negatively, with the relative importance or unimportance of the claimed constitutional right.

In the conventional public-law analysis, important constitutional precedents-the sort that should be afforded durable status - justify relaxing barriers to their procurement, and thus should be less costly to obtain. Conversely, within a private-rights adjudicatory model, judicial rulings, however important, are legitimated by the need to resolve actual cases or controversies that presumptively arise from circumstances beyond the claimant's control.

This chapter will argue that the public-rights adjudicatory model, while motivated by the admirable desire to generate valued constitutional precedent, produces an important unintended consequence. To the extent that the timing of constitutional litigation is driven by the happenstance of ideological sympathies of deciding jurists, the normative justification for affording the resulting precedent durable status is compromised once those conditions change in a manner that favors the other side. By contrast, the private-rights model makes constitutional precedent more costly to obtain on all sides, thereby enhancing the normative foundation for affording precedent durable status.

One reason why public-law scholars tend not to focus on this unintended consequence is that they typically view the underlying problem - the relationship between the importance of claimed rights and rules governing the creation of precedent-from an opposite perspective. Public-rights scholars typically frame the inquiry as follows: The more important the constitutional ruling being sought, the fewer the impediments that should stand in the way of obtaining it. ${ }^{1}$ In this analysis, when doctrinal stakes are high, traditional limitations on the ability to obtain precedent—ripeness, mootness, and standing principally among them—should be treated, at best, as avoidable nuisances that obstruct the litigation of pressing constitutional

\footnotetext{
${ }^{1}$ See, e.g., Jonathan Siegel, A Theory of Justiciability, 86 Texas L. Rev. 73, 109-110 (2007) (critiquing application of various timing-based justiciability doctrines that delayed the resolution of several high profile constitutional issues and questioning the benefit of seemingly pointless delays); Steven L. Winter, The Metaphor of Standing and the Problem of Self Governance, 40 Stan. L. Rev. 1371, 1510-11 (1988) (critiquing application of current standing doctrine as applied to City of Los Angeles v. Lyons, which resulted in denial of substantial public interest claim with intervening deaths prior to political reversal).
} 
claims. Despite these alternative framings-positing that important claimed rights justify relaxed justiciability barriers or positing that more stringent justiciability barriers enhance the respect accorded a constitutional precedent - the correlation between level of difficulty in obtaining a precedent and the importance of the underlying constitutional issue remains the same.

Before proceeding, it is important to clarify the meaning of cost. In this analysis, cost refers to the burdens of complying with formal, and often technical, doctrines that are preconditions to litigating a case in federal court in the United States. The specific set of relevant doctrines arises under the broad heading of justiciability, and within that category, involves those that inform the timing of federal litigation. ${ }^{2}$ Among those doctrines-ripeness, mootness, and standing — standing has proved the most important. These combined doctrines require that those seeking to litigate in federal court show a presently live claim, meaning one that is ripe and not moot, ${ }^{3}$ and that the claimant demonstrate an injury in fact, causation, and redressibility. ${ }^{4}$ In addition, the claim must be specific and personal, meaning that it should not belong to a third party or be legally diffuse. ${ }^{5}$ While the elements appear abstract and malleable, ${ }^{6}$ compliance costs are nonetheless quite real. Satisfying these combined justiciability requirements can delay, and in some cases obstruct, litigation that otherwise would lead to a desired constitutional precedent. ${ }^{7}$

Lowering the cost of obtaining precedent thus means relaxing the demands of these individual or combined requirements of justiciability as a means of litigating a case. The motivation for seeking to lower these costs is generally associated with the seemingly attractive composition of the relevant appellate court, or of the Supreme Court, which will ultimately resolve the case and, in so doing, potentially create the desired precedent. Conversely, these justiciability doctrines raise the cost of precedent procurement by presumptively divorcing the triggers to federal court litigation from such factors as beneficial appellate court composition.

Assuming that the justiciability criteria combine to demand something like fortuity as the dominant driver in timing federal court litigation, given the pendulum-like changes in judicial composition over time through the appointments and confirmation process, adhering to the various justiciability criteria makes it harder, and thus more costly, to optimally time cases for maximum doctrinal effect. Conversely, relaxing such criteria when cases present compelling

\footnotetext{
${ }^{2}$ This chapter does not discuss the political question doctrine, which although falling under the broad umbrella of justiciability is not connected to the timing of constitutional litigation.

${ }^{3}$ This briefly captures the requirements of ripeness and mootness. For a general discussion of these doctrines, see infra notes 16-17, and cites therein.

${ }^{4}$ These are the constitutional prerequisites to standing. See, e.g., Lujan v. Defenders of Wildlife, 504 U.S. 555, 56062 (1992); Allen v. Wright, 468 U.S. 737, 751-52 (1984).

${ }^{5}$ These are the prudential barriers to standing. Allen, 468 U.S. at 750-51.

${ }^{6}$ In a series of works, I have demonstrated that these arguments are often, although not invariably, overstated. See generally Maxwell L. Stearns, Standing Back from the Forest: Justiciability and Social Choice, 83 CAL. L. REV. 1309 (1995); Maxwell L. Stearns, Standing and Social Choice: Historical Evidence 144 U. PA. L. REV. 309 (1995); Maxwell L. Stearns, Constitutional Process: A Social Choice Analysis of Supreme Court Decision MAKING (2002).

${ }^{7}$ For some specific case illustrations, see infra Part I.A.
} 
claims lowers the cost of obtaining desired precedent by allowing litigants to better match desirable claims with a sympathetic appellate court.

Most public-law scholars implicitly assume that lowering the costs of obtaining desired constitutional rulings will not adversely affect the value of the precedent obtained. This chapter instead argues that the legal system is faced with an inevitable choice between a regime of lowcost/low-value or high-cost/high-value precedent. Although I personally conclude that the highcost/high-value precedent regime is preferable on the grounds that it generally improves stability of law, sharpens legal claims, and renders the overall process of both legislative and adjudicatory decision making more fair, that claim is the subject of a separate body of work. ${ }^{8}$ The central goal of this chapter is to demonstrate the inevitability of this choice.

The analysis that follows holds important implications for the history of litigation leading to Brown v. Board of Education; ${ }^{9}$ for the framing of the stare decisis inquiry in the jointly authored plurality opinion in the 1992 decision Planned Parenthood of Southeastern Pennsylvania v. Casey; ${ }^{10}$ and for the Supreme Court's agency-deference rules. ${ }^{11}$

\section{Public-Rights Versus Private-Rights Adjudicatory Models}

Several notable scholars, including, for example, Steven Winter, ${ }^{12}$ Jonathan Seigel, ${ }^{13}$ and Heather Elliott, ${ }^{14}$ embrace what I will refer to throughout this chapter as the "public rights model" of constitutional adjudication. Based on that model, these and other scholars have argued for relaxing barriers to justiciability, with a specific focus on standing. The goal is to broaden access among claimants with pressing constitutional claims to the federal courts in the hope of establishing desired constitutional precedent. Within the framework of the public-rights model, ${ }^{15}$ standing presents a set of unnecessary impediments to the formation of public law, and most notably to the development of constitutional doctrine.

The combined justiciability doctrines_ripeness, mootness, and standing_often stand in the way of desired constitutional precedent. These Supreme Court doctrines require claimants

\footnotetext{
${ }^{8}$ See generally supra note 6 , and cites therein.

${ }^{9} 437$ U.S. 483 (1954).

10505 U.S. 833, 854-61 (1992).

${ }^{11}$ National Cable \& Telecommunications Ass'n v. Brand X Internet Services, 545 U.S. 967, 982-83 (2005); United States v. Mead Corp, 533 U.S. 218, 234-35 (2001); Chevron U.S.A. Inc. v. Natural Resources Defense Council, 467 U.S. 837, 863-66 (1984).

${ }^{12}$ Winter, supra note 1.

13 Siegel, supra note 1.

${ }^{14}$ See Heather Elliott, The Functions of Standing, 61 STAN. L. REV. 459, 487-88 (2008) (suggesting that the use of standing in cases like Allen $v$. Wright undermines democratic values by preventing the litigation of pressing claims affecting the interests of particular minority groups).

${ }^{15}$ To be clear, these thoughtful scholars each have independent analyses worthy of individual consideration. In this discussion, I am focusing on a foundational assumption undergirding the public-rights adjudicatory model that each of their respective approaches shares in common. For a more focused response to the critiques of my standing analysis by Professors Heather Elliott and Jonathan Siegel, see Maxwell Stearns, "Grains of Sand" or "Butterfly Effect”: Standing and the Legitimacy of Precedent, __ ALA. L. REV. _ (forthcoming 2013).
} 
who otherwise meet the jurisdictional criteria to litigate in federal court to further establish that their suit is ripe, meaning not premature; ${ }^{16}$ that it is not moot, meaning that it remains live; ${ }^{17}$ and that it satisfies the constitutional and prudential standing requirements. Although ripeness and mootness sometimes present their own complex analyses, in general, standing has emerged as the most stringent justiciability barrier.

Standing has been described as governing the "who" and the "when" of constitutional litigation. ${ }^{18}$ Perhaps a more apt description is that standing identifies the necessary attributes for raising a presently live claim. In other words, once we ensure that the claim is ripe and not moot, standing focuses on the circumstances under which the federal judiciary is or is not permitted to adjudicate those claims that remain.

The historical origins of the doctrine have been amply surveyed elsewhere, ${ }^{19}$ and the specific contours of the doctrine have changed several times since its inception. Legal scholars generally trace the origins of standing to judicial efforts to stave off novel constitutional challenges targeting new forms of regulation in the Progressive Era. ${ }^{20}$ Although the earliest

\footnotetext{
${ }^{16}$ To establish that a claim is ripe, it is necessary to show that the claim is premised on a legal violation, most likely a constitutional one, that arises from the actual, rather than potential, application of a law. See Thomas v. Union Carbide Agric. Prod. Co., 473 U.S. 568, 580-81 (1985) (discussing ripeness requirements). The mere fact that a law has the potential to be applied in an unconstitutional manner is generally insufficient to establish a constitutional challenge to that law, although there again, this conventional understanding is subject to some exceptions. In the context of First Amendment claims, when a law yet to be applied threatens to chill speech or inhibit religious practice, would-be speakers or practitioners need not place themselves in harm's way by violating the law first and defending their conduct against an allegedly unconstitutional prosecution or by appealing the resulting conviction. See Buckley v. Valeo, 424 U.S. 1, 11-12 (1976) (permitting a pre-enforcement challenge to certain provisions of the Federal Election Campaign Act of 1971 alleged to violate the First Amendment). In addition, those convicted of criminal offenses are sometimes permitted to raise constitutional challenges to the laws under which they were convicted on the ground that it is overbroad, meaning that it is susceptible to unconstitutional applications, notwithstanding that it was constitutional as applied to them. These textbook presentations of exceptions to mootness and ripeness should be read with substantial caution. The relatively rarity of granting them shows that these exceptions do in fact prove the rule. For general discussions of mootness and ripeness, see Donald L. Doernberg \& Michael B. Mushlin, The Trojan Horse: How the Declaratory Judgment Act Created a Cause of Action and Expanded Federal Jurisdiction while the Supreme Court Wasn't Looking, 36 UCLA L. REV. 529 (1989); STEARNS, supra note 6, at 251-54.

${ }^{17}$ Mootness doctrine requires that claimant show that the relief will remedy an ongoing harm, unless the claim is subject to one of two exceptions: first, that the defendant has voluntarily suspended activity that, upon dismissal of the suit, she is apt to resume, or that the claim itself is capable of repetition yet evading review. See, e.g., Roe v. Wade, 410 U.S. 113, 125 (1973) (illustrating capability of repetition yet evading review exception); Northeastern Fla. Chapter of Associated Gen. Contractors v. City of Jacksonville, 508 U.S. 656, 662 (1993) (illustrating voluntary cessation exception). For a general discussion of mootness, see Evan Tsen Lee, Deconstitutionalizing Justiciability: The Example of Mootness, 105 HARV. L. REV. 605 (1992); STEARNS, supra note 6, at 254-56.

${ }^{18}$ Henry P. Monaghan, Constitutional Adjudication: The Who and the When, 82 YALE L.J. 1363 (1973).

${ }^{19}$ See Winter, supra note 1, at 1417-1458; Cass R. Sunstein, Standing and the Privatization of Public Law, 88 Colum. L. Rev. 1432, 1434-51 (1998); Cass R. Sunstein, What's Standing After Lujan? Of Citizen Suits, "Injuries," and Article III, 91 Mich. L. Rev. 163 (1992).

${ }^{20}$ See Winter, supra note 1, at 1457-58 (tracing formalization of standing doctrine to New Deal period); Sunstein, What's Standing, supra note 19, at 179 (same).
} 
incarnation of the doctrine in the New Deal was presumptive, ${ }^{21}$ thus allowing Congress to broaden or narrow standing by statute, beginning in the late Warren Court period and most notably in the Burger and Rehnquist Courts, ${ }^{22}$ the standing requirements came to be embedded in constitutional doctrine. ${ }^{23}$ By the early 1990s, the Court had extended the standing limits that govern claims arising under the Constitution itself to also cover federal statutory claims. ${ }^{24}$ These specific rulings remain in flux, ${ }^{25}$ as does standing more generally. Despite this, there are some relatively fixed parameters or guidelines, and it is these guidelines that often provide the fodder for the doctrine's detractors.

The Supreme Court has identified as constitutional standing elements the requirements of injury in fact, causation, and redressibility, and as prudential standing barriers the presumptions against raising the claims of others, raising diffuse claims, and raising claims challenging laws that distort particular markets in a manner that is alleged to injure the claimant. ${ }^{26}$ Critics argue that these combined constitutional and prudential standing barriers are, at worst, serious impediments to the development of desired constitutional doctrine, and at best, troublesome nuisances that merely cause unnecessary delays in developing doctrine. ${ }^{27}$ Either way, these scholars contend, the doctrines should be relaxed or abandoned, especially when doctrinal stakes are high. Although these two positions - standing as a serious impediment and standing as a petty annoyance to developing doctrine-are arguably in tension, that is not my immediate or primary concern. Instead, I will focus on the first and more troublesome objection, which presents standing and other timing-based justiciability barriers as significant obstructions en route to developing constitutional precedent.

\subsection{A tale of two cases $^{28}$}

Two historical case sequences nicely illustrate the preceding point. First, consider the case trajectory operating from the proceeds of the Garland Fund that comprised the NAACP

\footnotetext{
${ }^{21}$ Specifically, the Court presumed in favor of standing in cases presenting claims analogous to those arising in common law cases arising in tort, contract, or property, and presumed against standing more generally. William Fletcher, The Structure of Standing, 98 YALE L.J. 221, 226-27 (1988). In this regime, Congress generally had broad discretion, by statute, to flip these presumptions, thus conferring standing more broadly or more narrowly, as it saw fit. Id.

${ }^{22}$ For a more detailed discussion of the timing of the development of standing doctrine, see Maxwell Stearns, Standing at the Crossroads: The Roberts Court in Historical Perspective, 83 NOTRE DAME L. REV. 875, 896-903 (2008) (identifying cases in the early 1970s as providing constitutional status to elements of standing doctrine).

${ }^{23}$ Winter, supra note 1, at 1451 ("It was not until Doremus v. Board of Education that a full Court dealt with standing in exclusively constitutional terms, and not until Baker v. Carr and Flast v. Cohen that the Court fully discussed the new doctrine.”) (footnotes omitted).

${ }^{24}$ See Lujan v. Defenders of Wildlife, 504 U.S. 555, 578 (1992).

${ }^{25}$ See Friends of the Earth, Inc. v. Laidlaw Envt'l Services, 528 U.S. 167, 181 (2000) (determining that an environmental group has standing to bring a citizen suit even though there was no actual harm to the environment).

${ }^{26}$ See, e.g., Allen v. Wright, 468 U.S. 737, 750-51 (1984) (setting out constitutional and prudential standing barriers).

${ }^{27}$ See Siegel, supra note 1, at 75 (positing that the standing rules "throw a few grains of sand into the workings of the judicial branch but do not prevent it from grinding out a judgment”).

${ }^{28}$ Portions of this discussion are adapted from Stearns, supra note 15.
} 
strategy to bring an end to state-mandated segregation of public schools, ${ }^{29}$ a regime long sanctioned under the Plessy v. Ferguson separate-but-equal doctrine. ${ }^{30}$ This case trajectory ultimately culminated in Brown v. Board of Education, ${ }^{31}$ which ended race-based segregation in the South, at least as a matter of formal law. The NAACP strategists initially rejected a plan to present frontal attacks on one primary school in each southern state mandating race-based segregation on the ground that, under Plessy, each separate suit was destined to fail. Instead, they devised the ingenious plan to attack the most egregious denial of race-based equal protection by targeting graduate programs for which there was simply no counterpart for blacks, and then work down toward the most pressing cases of public educational at the high school, middle school, and then elementary school levels. Not only did this plan present the most obvious denials of state largesse as vehicles for distinguishing Plessy, but also it presented early challenges in contexts in which parental sensitivities over school choice were less pronounced, given that the early challenges involved institutions educating adults rather than school-aged children.

This strategy ultimately proved successful, so much so that others successfully mimicked it in other contexts. ${ }^{32}$ Despite this, the history of the litigation highlights the considerable costs that traditional justiciability criteria, of the sort we now associate with standing doctrine, ultimately imposed. One of the most significant cases in this trajectory was Missouri ex rel. Gaines v. Canada. ${ }^{33}$ In that case, Lloyd Gaines successfully challenged the regime for statefunded legal education in the State of Missouri. Missouri had offered its flagship state law school to qualified white law students, but had no counterpart law school for qualified black students. This case was particularly attractive as part of the litigation sequence because rather than focusing on the substantive differences between programs, here the claim was direct and to the point: Whites had a program; blacks did not. Instead, Missouri provided a tuition voucher for an out-of-state law school and transportation costs. This lawsuit made its way to the Supreme Court, and the result was to strike down the Missouri program.

That ruling, however, ultimately left the state with a choice. Missouri could elect to admit black students into its flagship school, or instead, it could create a separate law school for blacks. Missouri chose the latter course. After Missouri created an obviously inferior law school for blacks, the NAACP lawyers were most anxious to challenge it in a follow-up equal protection challenge. Alas, Lloyd Gaines disappeared. ${ }^{34}$ What happened to Lloyd Gaines has ever since been a mystery; what happened to the NAACP strategy, however, is well known.

\footnotetext{
${ }^{29}$ For a classic treatment of this historical period, see RICHARD KLUGER, SIMPLE JUSTICE: THE HiSTORY OF BROWN V. BOARD OF EDUCATION AND BLACK AMERICA'S STRUGGLE FOR EQUALITY (1977).

${ }^{30} 163$ U.S. 537 (1896). To be clear, nothing in Plessy itself mandated the "but equal” part of this formulation; instead, the statute mandating segregated railway cars, which the Court sustained, nominally required separate but equal. Nonetheless, Plessy has long been associated with this doctrinal formulation.

31347 U.S. 483 (1954).

32 STEARNS, supra note 6, at 189-90.

33305 U.S. 337 (1937).

${ }^{34}$ Lucile H. Bluford, The Lloyd Gaines Story, 32 J. EDUC. SoC. (1952).
} 
The loss of Gaines as the named litigant suspended the careful case sequencing that would have allowed the challenge to progress from a complete denial of programming based on race to the denial of comparable-quality programming based on race. Instead, the NAACP had to await another litigant, and another case. It took a full ten years until the Supreme Court revisited the issue that began with the Gaines litigation in Missouri. In Sipuel v. Board of Regents of the University of Oklahoma, ${ }^{35}$ a black woman who had been denied admission to the flagship Oklahoma state law school because of her race succeeded before the Supreme Court. This time, Oklahoma had the choice to admit black students or to create an alternative black law school. It chose the latter. That same year, in Fisher v. Hurst, ${ }^{36}$ the Supreme Court rejected the challenge that Oklahoma's new law school for blacks was unequal to the flagship state law school for whites.

Although, of course, there is no way to know if the result would have differed had Gaines been available as a litigant in the earlier case, it very well might have been. In both cases, the states, Missouri and Oklahoma, behaved similarly in response to the Supreme Court's decision demanding either that a qualified black student be admitted to the existing state law school or that the state create a black law school. In the intervening decade, the Supreme Court had undergone major compositional changes. These involved appointments by Democratic Presidents, Franklin Delano Roosevelt and Harry Truman. Although it is tempting to assume that desegregation cases are a liberal project, that greatly oversimplifies the matter. Progressive liberalism, which dominated much of that era, often equated to judicial restraint as a means of affording legislative choice over policy.

Ultimately, even the loss of Lloyd Gaines proved a temporary setback as far as the caselaw trajectory is concerned. Eight years following Fisher, with a series of cases in between, including most notably Sweatt v. Painter, ${ }^{37}$ the Supreme Court ultimately announced an end to race-based segregation in public schools in the landmark decision Brown v. Board of Education. ${ }^{38}$ Of course that case, and perhaps more notably the egregious inadequacy of the "with all deliberate speed" formulation that followed re-argument over remedy in Brown II generated another case trajectory designed to effectuate the Brown mandate. ${ }^{39}$ The larger point for our purposes is that the conventional understanding, requiring a specific litigant with an actual injury caused by the government that is redressible by the courts, is indeed burdensome.

The second illustration involves the later case-law trajectory that resulted in locating a right of privacy within the Fourteenth Amendment Due Process Clause, and ultimately

\footnotetext{
35332 U.S. 631, 632 (1948).

36 U33 U.S. 147, 148-49 (1948).

37339 U.S. 629 (1950).

38347 U.S. 483, 493-95 (1954).

${ }^{39}$ See, e.g., Swann v. Charlotte-Mecklenburg Board of Educ., 402 U.S. 1, 15 (1971) (providing broad equitable powers for purposes of enforcing southern school desegregation decrees); Keyes v. School Dist. No. 1, 413 U.S. 189, 209-10 (1972) (determining who bears the burden to prove that state policies did or did not produce predominantly one-race schools in districts that had not mandated segregation).
} 
established the rights of married couples to use contraceptives and of women to terminate unwanted pregnancies, at least prior to viability. Unlike the sequence of cases leading to Brown, these right-of-privacy cases did not arise as part of a coordinated litigation campaign. Despite this, the individual cases built upon each other in a similar fashion, with the right to marital privacy creating a foundation for an expansion outside the marital context, and for a reconceptualization of that right to include the controversial right to abort an unwanted pregnancy.

In Poe v. Ullman, ${ }^{40}$ the Court rejected an early challenge to the same Connecticut contraception-ban statute that the Supreme Court eventually struck down, ${ }^{41}$ concluding that the challenge was not ripe. The result was a four-year delay in addressing that challenge even though the later case, Griswold v. Connecticut, was presented under circumstances that appear contrived, involving a claim by the prescribing physician who contended that the couple using contraceptives would be unwilling to press such a claim on their own behalf. ${ }^{42}$ In this instance, the intervening judicial appointments were far less dramatic than those that followed Gaines and might even have been beneficial from the perspective of those bringing the constitutional challenge. Notably, President Kennedy replaced Felix Frankfurter with Arthur Goldberg and Charles Whitaker with Byron White. Although both Goldberg and White filed separate concurrences, they did join the seven-to-two majority opinion striking down the Connecticut statute in Griswold.

Even if one takes the view that Poe and Griswold are primarily, or exclusively, symbolic - despite Justice Douglas's alluring prose, there does not appear to be any contemporaneous evidence of Connecticut sex police searching the "sacred precincts of marital bedrooms for telltale signs of the use of contraceptives" ${ }^{43}$ - that is certainly not true of the far more significant cases that arose later in the privacy case-law trajectory. Of course, this case sequence culminated in Roe v. Wade ${ }^{44}$ holding that the right of privacy extends far enough to include a woman's right to terminate an unwanted pregnancy. ${ }^{45} \mathrm{~A}$ different ruling in Poe $v$. Ullman might have changed this eventual case trajectory.

As is always so with counterfactuals, we can only speculate as to how these two wellknown case trajectories might have played out absent a set of justiciability barriers. And it is notable that in the Lloyd Gaines litigation, it was not a judicial decision that thwarted standing; rather it was the clear understanding among the lawyers that absent an actual affected litigant the case could not proceed. Although there are other illustrations of this basic insight, these cases amply demonstrate the central contention of "public rights" scholars: These and other important

\footnotetext{
${ }^{40} 367$ U.S. 497 (1961).

${ }^{41}$ Griswold v. Connecticut, 381 U.S. 479, 485-86 (1965).

${ }^{42} I d$. at 480 (explaining relationship between the physician, who was convicted, and the patients, a married couple, gaining access to a contraceptive).

43381 U.S. at 485.

${ }^{44} 410$ U.S. 113 (1973).

${ }^{45} \mathrm{Id}$. at 153.
} 
constitutional claims are, at best, delayed, as in Poe/Griswold, when the federal judiciary interposes justiciability barriers between willing litigants and the constitutional claims they seek to advance; and, at worst, denied, as in Fisher v. Hurst, if the changed circumstances between the initial presentation and the eventual opportunity—with "i”"s dotted and " $\mathrm{t}$ ”s crossed—result in an adverse ruling as compared with how an earlier case presenting the same substantive issue might have been resolved absent the justiciability barrier.

\subsection{The public-rights view}

I am classifying the group of scholars advancing this understanding of justiciability as embracing a "public rights" adjudicatory model. The central premise of the public-rights model is that constitutional claimants present these and other important constitutional claims specifically to generate valued constitutional precedent, or, stated differently, to create "public rights." The specific cases, along with any particular interests that litigants hold, whether in the form of expected damages or injunctive relief, are ultimately a byproduct, and in the broader scheme, an inconsequential one at that, of the larger adjudicatory mission of establishing desired constitutional precedent. Whatever private benefits inure to the nominal litigants are merely the justificatory vehicle or trigger that creates the opportunity for the sought-after ruling. In this model, allowing technical details about justiciability defects to undermine such litigation misconceives both the means and ends of the process of constitutional adjudication.

Within this public-rights model, the normative justification for resolving a dispute implicating a constitutional right is positively correlated with the normative importance of the claimed constitutional right itself. For pressing claims, therefore, standing should be relaxed so that the federal judiciary can fulfill its core mission of articulating constitutional precedent. And by negative implication, for ordinary litigation, which tends to involve more mundane claims, constitutional or otherwise, it is acceptable to burden litigants with traditional impediments, or such business-as-usual requirements as the strictures of standing, ripeness, and mootness.

\subsection{The private-rights alternative view}

Let us now consider an opposing perspective on the nature of constitutional adjudication, which I will refer to as the "private rights" adjudicatory model. In this camp, I will include Lea Brilmayer, ${ }^{46}$ Robert Pushaw, ${ }^{47}$ and myself. ${ }^{48}$ For those embracing a private-rights model, the fundamental premises about the nature of the adjudicatory process are generally unaffected by the level of importance associated with the underlying substantive claim, constitutional or otherwise. Whether we are discussing ordinary litigation—of the A hits B; B sues A sort—or

\footnotetext{
${ }^{46}$ Lea Brilmayer, The Jurisprudence of Article III: Perspectives on the "Case or Controversy" Requirement, 93 Harv. L. Rev. 297 (1979).

${ }^{47}$ Robert J. Pushaw, Jr., Limiting Article III Standing to “Accidental” Plaintiffs: Lessons from Environmental and Animal Law Cases, 45 Ga. L. Rev. 1 (2010).

${ }^{48}$ Maxwell L. Stearns, Standing Back from the Forest: Justiciability and Social Choice, 83 CAL. L. REV. 1309 (1995); Maxwell L. Stearns, Standing and Social Choice: Historical Evidence, 144 U. PENN L. REV. 309 (1995).
} 
high-level constitutional adjudication, the adjudicatory process itself remains centered on dispute resolution. To be clear, this is not to say that those embracing the private-rights model are systematically duller than public-rights scholars (at least I hope not). Scholars in this camp are well aware that those litigating high-profile constitutional claims are doing so to establish highprofile constitutional precedents.

Instead, within this framing, judicial creation of precedent, including constitutional precedent, is, as a formal matter, treated as the byproduct of case resolution, rather than the other way around. Because cases more generally (setting aside the sort of cases I have previously described) are triggered by stochastic events, meaning that they are largely randomly driven responses to circumstances beyond the control of the claimant, ${ }^{49}$ in general case law is not optimally "timed." The process of timing is passive, not active, and the consequence is that precedent is subject to a never-ending set of factors-docket delays; discovery delays; motion delays; changes in judicial appointments; randomly comprised appellate panels; unpredictable grants or denials on relevant discretionary dockets - that individually and collectively are well beyond the control of any litigant. ${ }^{50}$ Indeed, many important procedural rulings arise from cases that were themselves centered on altogether unrelated substantive points of law.

In general, we expect regular litigants, those bringing common law claims, regulatory claims, and statutory claims, to comply with the complex set of rules governing adjudicatory timing. And although constitutional adjudication is undoubtedly motivated by constitutional precedent, within the private-rights model the basic adjudicatory assumptions nonetheless remain. This holds without regard to the importance of the claim that the litigant seeks to advance. Instead, private-rights adjudicatory scholars seek to separate, as much as practicable, the preferred timing of cases from the coincidence of favorable circumstances respecting those who are likely to resolve the dispute.

Even assuming that constitutional precedent is more important than other bodies of precedent, ${ }^{51}$ within the private-rights model, that does not change the essential dynamics required to create precedent. These include a claim that is ripe and not moot, and a litigant suffering a first-person and non-diffuse injury caused by the defendant that is susceptible of meaningful judicial redress. These requirements are each subject to considerable criticism among scholars, but the essential insight for our immediate purposes is simply this: Individually and in

\footnotetext{
${ }^{49}$ Of course criminal defendants "control” the circumstances that give rise to the litigation in which their legal claims, including constitutional defenses, arise. With rare exception, however, they do not engage in the criminal activity with the purpose of creating precedent. Quite the contrary, those who are guilty of the underlying offenses do so with an eye to evading detection and, thus, succeeding in their crimes.

${ }^{50}$ For a further exploration of these sorts of adjudicatory delays caused by justiciability, see Stearns, supra 15 (arguing that such justiciability factors cause impediments to developing doctrine that are potentially more akin to butterfly effect than to the mere tossing of grains of sand into the adjudicatory gears).

${ }^{51}$ This is not an inevitable conclusion. For many, and perhaps most, individuals, non-constitutional rulings and any number of other methods of affecting legal policy might have a greater direct impact on their lives. Despite this, for purposes of this analysis, I am assuming there is a special significance to constitutional precedents.
} 
combination, each captures a characteristic feature of the traditional, non-high-profile lawsuit. When B sues A after having been hit, there is little question of injury, causation, and redressibility. There is also no concern that B is presenting a claim that is distinctly his. Publicinterest litigation certainly complicates these matters, but one way to think about the justiciability requirements is that however imperfect they might be, they are designed to ground litigation in a manner that, as in the ordinary case, seems less likely to be driven by considerations of strategic timing.

\subsection{Form versus motive}

The distinction drawn here between those who embrace a public-rights or private-rights adjudicatory model goes to the form of, rather than the motivation behind, the litigation. Otherwise the private-rights model and those who embrace it risk appearing shockingly naïve. There is no doubt, for example, that many cases, including those previously discussed, were motivated more by the desire for precedent than by the desire for specific litigant relief. Those pressing the desegregation or sexual-privacy claims were almost certainly motivated by a desire to create public law even if they also hoped that they themselves, or those they care for, would receive some eventual benefit. Instead, the private-rights model rests on the assumption that the process through which all precedent-creating adjudication occurs is improved if the judiciary behaves as if the general model of adjudication-grounded in private-rights resolution with precedent as a byproduct rather than grounded in creation of precedent with private-rights resolution as a byproduct-remains without regard to the importance of the sought-after precedent.

We can now revisit this chapter's central thesis: A key premise of the public-rights model - that the relative ease of constitutional lawmaking should be a function of the importance of the claimed constitutional right—creates an unintended and deleterious effect from the perspective of those who care deeply about highly valued constitutional precedent. To the extent that the timing of constitutional litigation is driven by such factors as present political support for developing doctrine or the ideological sympathies of present jurists, the normative justification for respecting the precedential status of a ruling obtained is inevitably relaxed when those conditions change. By contrast, the private-rights model raises the cost of obtaining constitutional precedent and thereby enhances the normative foundation for respecting inevitably hard-fought rulings as precedent regardless of the fortuity of such changed circumstances, including most notably changes in the ideological composition or predilections of deciding jurists.

Precedent that is more costly to obtain should be more durable than precedent that is cheaper to obtain. The analysis thus suggests a normative tradeoff: Those seeking to relax requirements for obtaining constitutional precedent must accept a diminished precedential value, whereas those seeking to retain requirements for obtaining constitutional precedent benefit from higher precedential value. The central claim of this chapter is that this tradeoff is an inevitable 
design feature rather than a bug in the system. It is not possible to benefit from lower-cost constitutional adjudication while also benefiting from durable precedent. And this implies that those who are most solicitous of employing the federal judiciary to create constitutional precedent might themselves compromise the eventual value of such precedent by successfully claiming that the underlying issues are sufficiently compelling to warrant relaxation of traditional requirements for adjudication.

\section{Another Look at Justiciability: Linking Standing to the Private-Rights Model}

In separate works, I have demonstrated that standing doctrine raises the cost to litigants of manipulating the timing, and thus the substantive development, of constitutional precedent. ${ }^{52}$ It does so by making it more difficult to present constitutional cases in a preferred ordering to maximize doctrinal effect. The analysis, which rests largely on social-choice theory, reveals the circumstances under which judicial preferences on an appellate judicial panel are prone to the phenomenon of cycling. Cycling implies that members of a multi-member decision-making body, including the nine-justice Supreme Court, will sometimes hold preferences that thwart the general condition of transitivity, or A preferred to B preferred to C implies A preferred to C. When a cycle arises, three persons, each holding internally rational, or transitive, preferences (for example $\mathrm{ABC}$, BCA, $\mathrm{CAB}$ ), will, when combining their preferences, discover a cycle such that the group as a whole prefers $\mathrm{A}$ to $\mathrm{B}$ and $\mathrm{B}$ to $\mathrm{C}$, but $\mathrm{C}$ to $\mathrm{A}$.

In a series of individual Supreme Court cases, and in groups of combined cases, the Supreme Court has manifested evidence of underlying cycling preferences. ${ }^{53}$ Within individual cases, the potential for cycling arises in a subset of cases in which the justices generally agree to the dispositive issues on which the case turns but disagree as to how those issues should be resolved. The particular, and relatively uncommon, condition that generates the cycle arises when a voting path that follows the separate resolution of each dispositive issue logically compels the dissenting result. This phenomenon arises when those who agree on the actual result, or judgment, nonetheless base their respective judgments on opposite resolutions of both dispositive issues.

Cycling preferences also arise across multiple cases. This phenomenon arises, most notably, in paired cases in which each has majority support for a seemingly opposite judgment but a crossover majority believes that the two cases cannot be legally distinguished. That crossover majority is inevitably split over how the cases should be resolved, with one subgroup preferring

\footnotetext{
52 See supra note 48, and cites therein.

53 Illustrative cases include Kassel v. Consolidated Freightways Corp., 450 U.S. 662 (1981); Miller v. Albright, 523 U.S. 420 (1998); National Mut. Ins. Co. v. Tidewater Transfer Co., Inc., 337 U.S. 582 (1949). See also MAXWELL L. Stearns, Constitutional Process: A Social Choice AnAlysis of Supreme Court Decision MAKing 97-156 (2002) (collecting and analyzing cases based on characteristic features of multidimensionality and asymmetry).
} 
that both challenges be rejected and another preferring that both be sustained, but nonetheless shares in common a rejection of the minority argument that seeks to distinguish the cases. ${ }^{54}$

The phenomenon of cycling across multiple cases is particularly relevant because it helps to explain why ideologically motivated interest groups seek to further their agendas through preferred case orderings. Assume a majority of justices sincerely believes that two cases that have majority support for opposing rules are nonetheless indistinguishable. Further assume this majority adheres to precedent. If these cases were presented sequentially rather than simultaneously, the case ordering would potentially control the development of doctrine in both cases. Under these conditions, case A followed by case B produces opposite holdings in both cases as compared with case $B$ followed by case $A$. That is because the crossover majority in the second case ( $\mathrm{B}$ or $\mathrm{A}$ ) will vote to resolve that case consistently with the binding precedent established in the first case (A or B). And, most notably, this holds even assuming that the cases reach the Supreme Court in rapid succession with no intervening change in membership.

To be sure, pursuing a favorable case trajectory can be a noble endeavor. Perhaps the most notable illustration is the series of previously discussed cases comprising the eventually successful NAACP strategy to rid equal protection of the Plessy regime and replace it with Brown. The question here, however, is not whether the trajectory and eventual doctrine were compelling - obviously they were-but rather whether part of what made it endure, and indeed has made it something of an icon within constitutional doctrine, was the very difficulty of accomplishing it. The burdens of the traditional private-rights adjudicatory model were not theoretical; they were quite real. That, after all, is the lesson of Lloyd Gaines.

Within the social choice analysis of justiciability, standing plays a central role. That doctrine in its modern form has substantially raised the cost to ideologically motivated litigants of creating constitutional doctrine. And yet, it is mistaken to posit that it has done so relative to the line of cases culminating in Brown. Rather, that line of cases aptly illustrates the nature and benefits of the private-rights adjudicatory model. Some scholars imagine that standing merely

\footnotetext{
${ }^{54}$ For a pair of case illustrations, see STEARNS, supra note 53, at 170-180 (discussing Crawford v. Bd. of Educ., 458 U.S. 527 (1982); and Washington v. Seattle School Dist. No. 1, 458 U.S. 457 (1982)). In Crawford, a majority rejected a challenge to a California constitutional amendment, enacted through a referendum process, that prevented state courts from ordering busing as a means of integrating public schools unless the court first determined that such a remedy was necessary to avoid violating the Fourteenth Amendment Equal Protection Clause. 458 U.S. at 542. In Seattle, a majority struck down a constitutional amendment enacted as an initiative that prevented local school boards from employing busing as a means of integrating public schools unless doing so was necessary to remedy a violation of either the state or federal equal protection requirements. 458 U.S. at 470. Although these cases were decided the same day, a crossover majority, comprising four justices who agreed with the Crawford holding and who dissented in Seattle, and one justice who agreed with the Seattle holding and dissented in Crawford, expressed in separate opinions that the two cases were constitutionally indistinguishable, and thus should have been resolved in the same manner. See Crawford, 458 U.S. at 547-48 (Marshall, J., dissenting) (reasoning that there is no distinction between the two cases and disagreeing that California's action could be constitutional while Washington's is not); Seattle, 458 U.S. at 494 n.8 (Powell, J., dissenting) (noting the Court’s holding in Crawford that "the Equal Protection Clause is not violated by the mere repeal of race-related legislation or policies that were not required by the Federal Constitution" and reasoning that the same logic should apply in Seattle) (internal quotations omitted).
} 
delays inevitable constitutional rulings, perhaps by a period of two to four years. ${ }^{55}$ If all that standing accomplishes is delay of inevitable rulings, rulings of particularly high value, is the doctrine worth the keep?

Public-law scholars maintain that relaxing standing would remove what they regard as the doctrine's pointless constraints, which undermine the judiciary's central lawmaking function. In an important respect, however, the criticism misses both the main insight of the social choice account of standing and one of the central lessons of the history on which it rests. Although the social choice model of standing demonstrates the possibility of cycling in a snapshot mannermeaning with no change in Supreme Court membership and no other changes than the order of case decisions - public-rights scholars are sensitive to the more serious problem that losing the opportunity to press a claim today might well result in a far less attractive opportunity, depending on what the Supreme Court looks like, tomorrow. Over a host of substantive constitutional issues, the Roberts Court is less attractive to liberal scholars and more attractive to conservative scholars than were the Rehnquist Court, the Burger Court, and certainly the Warren Court. As the replacement of Justice O'Connor with Justice Alito amply demonstrates, even a single change in the Court's staffing can potentially alter the conditions for litigating a case. ${ }^{56}$

The implications of the social-choice account should not be misunderstood. Although the model demonstrates conditions under which litigants can benefit from using favorable case orderings to affect precedent even absent any changes in judicial staffing, these incentives are only enhanced with the very real prospects of actual changes in judicial staffing in the period between when an attempted case is thwarted by justiciability criteria and when an actual case is litigated after those criteria are met. ${ }^{57}$

\footnotetext{
${ }^{55}$ See Siegel, supra note 1, at 110 (discussing the resolution of zoning issues in Village of Arlington Heights v. Metro. Hous. Dev. Corp., 429 U.S. 252 (1977), two years after the same issues were avoided on justiciability grounds in Warth v. Seldin, 422 U.S. 490 (1975), and the resolution of affirmative action in Regents of the Univ. of Cal. v. Bakke, 438 U.S. 265 (1978), four years after the issues were avoided in DeFunis v. Odegaard, 416 U.S. 312 (1974)).

${ }^{56}$ It is, of course, impossible to know how any case might have been resolved with different Supreme Court membership. That said, the outcomes in any of the following landmark cases might have differed absent Justice O'Connor's replacement with Justice Alito: Parents Involved v. Seattle School District No. 1, 551 U.S. 701, 747-48 (2007) (striking down voluntary race-affirmative efforts by Louisville, Kentucky and Seattle Washington to prevent reversion to single race schools), District of Columbia v. Heller, 554 U.S. 570, 592 (2008) (interpreting the Second Amendment to protect an individual right to bear arms as applied against a District of Columbia Handgun ordinance, and overturning United States v. Miller, 307 U.S. 174 (1939)); McDonald v. City of Chicago, 130 S. Ct. 3020, 3050 (2010) (striking down municipal ordinance restricting access to handguns by, alternatively, incorporating Heller or finding the second amendment right a protected Fourteenth Amendment privilege or immunity); Citizens United v. Federal Elections Commission, 558 U.S. 310, 130 S. Ct. 876, 900 (2010) (striking down campaign contribution limits of corporations and holding that corporations are persons for purposes of purposes of political spending). ${ }^{57}$ For a more detailed analysis, see Stearns, supra note 15. In that article, I more carefully parse the standing doctrines to respond to claims that they are mere inconveniences, akin to throwing Jonathan Siegel's "few grains of sand" in the adjudicatory gears. See id. In this chapter, I instead begin with the premise that these rules impose meaningful barriers to the imposition of precedent and ask if they are worth their keep from the perspective of those seeking valued constitutional precedent. Answering this question requires a normative defense-independent of the success of particular standing rules_ - of the cost-raising function of standing in precedent procurement.
} 
Although standing and other justiciability doctrines raise the cost of procuring precedent, they also enhance the durability of precedent. This is necessarily so for two reasons: First, the cost of procuring a contrary precedent is substantially higher as well in a regime that adheres to requirements of justiciability; and second, normatively burdensome acquisition provides an independent basis for respecting the outcomes of hard-fought battles in the judiciary, as compared with the outcomes of precedents that were merely the product of convenience. The cost of obtaining these precedents thus provides added normative status.

One way to demonstrate this second point is to compare the Supreme Court's alternative approach to rules obtained at the agency level that are procured in response to changing political conditions, rather than to fortuitous circumstances that require a decision to be issued at a given moment in time. We now consider the Supreme Court's agency-deference rules, and then return for a comparison with the Supreme Court's doctrine of stare decisis. The analysis further supports the intuition that the benefit of a payoff is inversely correlated with the political cost of its procurement.

\section{From Rent-Seeking to Agency-Deference Rules}

As is often the case, it is helpful to look at the question under consideration from another side. Here we consider the relationship between public- versus private-rights adjudicatory models and the normative foundations for durable precedent by turning to a literature that focuses on judicial payoffs for something far less high-minded, namely special-interest rents procured through the legislative process. In a landmark paper, William Landes and Richard Posner explored the normative foundations of the independent judiciary ${ }^{58}$ The authors reasoned that an independent judiciary increases the durability of legislation, including, in particular, payoffs to interest groups procured through the congressional lawmaking process or state lawmaking processes, as compared with an alternative dependent judiciary. That is because elected judges are not as meaningfully insulated from political pressures and thus remain answerable to legislatures for renewed appointments and perquisites of office.

Landes and Posner reasoned that one benefit of the independent judiciary is extending the durability of legislatively conferred rents. Judicial independence encourages this prolongation of rents by increasing the likelihood that Article III judges will construe ambiguous legislation based on the preferences of the enacting legislature, as compared with an elected judiciary, which is more prone toward being solicitous of the concerns of the present legislature. In effect, Landes and Posner claim that judicial independence increases durability and thus the value of implicit interest-group bargains.

A number of notable theorists have resisted this account of the independent judiciary on various grounds. Here, I will take up two related arguments. Jonathan Macey maintains that

\footnotetext{
${ }^{58}$ William M. Landes \& Richard A. Posner, The Independent Judiciary in an Interest-Group Perspective, 18 J.L. \& ECON. 875 (1975).
} 
federal judges should thwart interest group payoffs and that doing so is consistent with an overarching theory of constitutional design that makes rent-seeking more difficult or costly to procure ${ }^{59}$ Einer Elhauge, focusing on the federal judiciary specifically, maintains that, contrary to Landes and Posner, courts can, and should, construe statutes consistently with the preferences of the present Congress, rather than a Congress long prorogued, as a means of improving overall political satisfaction. ${ }^{60}$ According to Elhauge, construing statutes in light of today's congressional preferences rather than those of the enacting legislature enhances present political satisfaction by allowing today's members of Congress to influence all presently ambiguous legislation that is interpreted during their term, as opposed to having such legislators only influence the meaning of ambiguous legislation that they themselves enacted, now and into the indefinite future. ${ }^{61}$

One of the most important implications of Elhauge's thesis involves agency-deference rules, and specifically Chevron deference. ${ }^{62}$ Under Chevron, courts defer to agency interpretations of ambiguous statutory provisions within the agency's jurisdictional domain even if the courts would have interpreted those provisions differently. This rule is cabined by Mead, ${ }^{63}$ which requires as a precondition to Chevron deference that the interpretation follow quasi-adjudicatory or quasi-rulemaking procedures, as opposed to a less-formal, and non-vetted, bureaucratic decision. Brand $X$ reinforces the Chevron rule,${ }^{64}$ holding that even if the agency interpretation follows a contrary Supreme Court ruling interpreting a federal statute, under Chevron the later agency interpretation trumps the prior judicial one.

Although this appears in tension with the famous admonition in Marbury v. Madison, "it is emphatically the province and duty of the judicial department to say what the law is," 65 the propositions are reconcilable. If we accept the Chevron premise that agency interpretation trumps judicial interpretation of ambiguous provisions in federal statutes, Brand $X$ ensures that the order of decision — court then agency versus agency then court—does not drive the substantive meaning of the statute. Whether the agency interpretation leads or follows, the agency interpretation governs. Conversely the judiciary need only afford lesser deference,

\footnotetext{
${ }^{59}$ Jonathan R. Macey, Promoting Public-Regarding Legislation Through Statutory Interpretation: An Interest Group Model, 86 Colum. L. REV. 223 (1986).

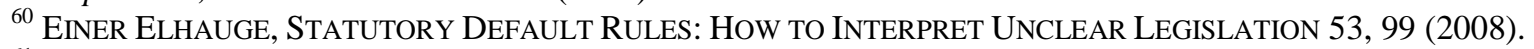

${ }^{61}$ An aside: Each year, I ask my public choice students which regime they would prefer were they a member of Congress, and the class is generally split. Personally, I'd prefer the contrary regime, meaning having my preferences over bills I passed carry forward rather than having future congressional preferences govern the interpretation of those statutes and my preference influence the interpretations of past statutes in cases construing them during my hypothetical congressional term. This choice does not admit of a right or wrong answer, of course, and my preferences might well be idiosyncratic (although my admittedly nonscientific polling seems not to show that). The point is that there's no reason to assume that members of Congress, as a class, necessarily will hold one preference systematically over the other.

${ }^{62}$ Chevron U.S.A., Inc. v. Natural Resources Defense Counsel, 467 U.S. 837 (1984).

${ }^{63}$ United States v. Mead Corp., 533 U.S. 218 (2001).

${ }^{64}$ National Cable \& Telecommunications Association v. Brand X Internet Services, 545 U.S. 967 (2005).

${ }^{65} 5$ U.S. (1 Cranch) 137, 177 (1803).
} 
applying Skidmore v. Swift \& Co. ${ }^{66}$ under which agency constructions are considered for their persuasiveness, to agency rulings that are not the product of proper channels, again, whether those decisions pre- or post-date federal judicial interpretations.

Einer Elhauge's interpretive theory is in tension with the Landes and Posner theory of the independent judiciary. Whereas Landes and Posner contend that the federal judiciary is structured to afford special weight to contemporaneous legislative preferences, thereby prolonging the life of special-interest bargains well past that of the enacting legislature, Elhauge instead maintains that the federal judiciary can, and should, give special weight to "enactable," meaning present-day, congressional preferences.

The debate over the durability of legislative preferences respecting judicial interpretation of ambiguous statutory language bears important parallels to the debate over the durability of judicial precedent. And in the context of agency-deference rules, Elhauge appears to have a trump card: Under Chevron, courts do in fact provide special weight to present agency interpretation, and they are expected to do so without regard to their own independent assessment of the preferences of the enacting legislature, at least when the statutory mandate is ambiguous. If, as Elhauge maintains, agency interpretations are a reasonable proxy for enactable congressional preferences, then Chevron seems to support the intuition that the goal of judicial decision making is to enhance present political satisfaction. And yet, I will argue, Chevron is ultimately reconcilable with the opposite intuition respecting the durability of constitutional precedent.

Notice that Chevron deference produces results that are relatively easy to obtain. By easy, I do not mean that less work is involved in generating a quasi-legislative or quasi-adjudicatory agency decision than in obtaining a judicial victory, even in the Supreme Court. The ease or difficulty of obtaining results, as I am using those concepts here, is not a statement about exertion. Rather, it is an assessment of the likelihood of obtaining a preferred outcome as a consequence of changed political conditions, and specifically changed conditions within the relevant institution, court or agency, favoring a desired result, as opposed to awaiting a justificatory trigger to decision that is randomly associated with such favorable conditions. It is certainly easier to have an agency favorably interpret an ambiguous statutory provision than it is to enact clarifying legislation in the event that the agency, or a federal court, gets that interpretation wrong. It is also easier to obtain a favorable agency interpretation than a favorable judicial one. That is because agencies can more freely change policies in response to changed political sensibilities. A newly staffed agency, like a newly staffed Congress, can reverse course consistent with changed ideological predilection. By contrast, courts need a much stronger basis

${ }^{66} 323$ U.S. 134, 140 (1944). 
for doing so, and this is especially true when construing a statute, ${ }^{67}$ although it is also true when construing constitutional precedent.

Of course there is a flip side to the Chevron rule. Although favorable agency interpretations are in this sense more easily obtained, they are also less durable than a judicial interpretation. That is because an earlier judicial interpretation pursuant to a case or controversy can only be reversed by a statute or by judicial overruling, and judicial overruling of statutory interpretation is even more difficult than judicial overruling of constitutional precedent. To change an agency interpretation, simply restaff the agency. Accomplishing that result politically is not easy to do, of course, but the point is that a change in political control is itself generally sufficient for a change in the direction of regulatory policy. And indeed, I would suggest that this might provide the basis for a more robust account of Chevron deference than Elhauge's account of enhanced political satisfaction taking the form of enactable preferences. In this analysis, what Chevron accomplishes is raising the stakes of political outcomes. It does so by signaling to interest groups, and ultimately to the electorate, that inasmuch as it affects the direction of regulatory policy, agency construction of myriad federal statutes can be altered when political fortunes, and thus agency staffing, change.

Consider in light of this analysis Matthew Stephenson's alternative account of Chevron deference. ${ }^{68}$ Stephenson maintains that contrary to conventional understanding, tighter presidential control of agency policy through a unitary executive might reduce political satisfaction as compared with a regime of insulated, independent, regulatory agencies. Stephenson measures such satisfaction by the political preferences of the median electoral voter. Stephenson observes that presidential candidates invariably occupy policy space some distance to the right or left of the electoral median voter, and posits that as a result, the tighter the executive control of agency policy, the more likely such policy is to occupy positions distant from the median voter. By contrast, relatively insulated agencies are more likely, over time, to hold positions that converge on the median voter. This follows from the cumulative effect of Democratic and Republican staffing of agencies that to the extent of independence are afforded some degree of political insulation.

Consider a simple, and stylized, illustration. Imagine a political spectrum evenly spaced at ten-percent intervals from liberal to conservative, with elected Democratic presidents generally occupying positions $40 \%$ from the extreme left end of the spectrum and elected Republican presidents generally occupying positions $40 \%$ from the extreme right end of the spectrum.

\footnotetext{
${ }^{67}$ For a general discussion, see William N. Eskridge, Overruling Statutory Precedents, 76 GEORGETOWN L.J. 1361 (1988). Eskridge observes:

The Court applies a relaxed, or weaker, form of that presumption when it reconsiders its constitutional precedents, because the difficulty of amending the Constitution makes the Court the only effective resort for changing obsolete constitutional doctrine. Statutory precedents, on the other hand, often enjoy a super-strong presumption of correctness.

Id. at 1362.

${ }^{68}$ Matthew C. Stephenson, Optimal Political Control of the Bureaucracy, 107 MICH. L. REV. 53, 71-75 (2008).
} 
Agencies that produce policy as a product of unitary executive influence will, following each election cycle, place policy at or about these positions, $10 \%$ to the left of the median voter for Democratic presidents and $10 \%$ to the right of the median voter for Republican presidents. Either way, the result is to thwart the preferences of $60 \%$ of voters. By contrast, a regime of independent agencies would generate policies that tend toward the median voter, and in doing so, this regime would enhance present political dissatisfaction.

This dynamic is all the more pronounced when we compare the output of agencies, on the one hand, with the output of Article III courts on the other. However insulated independent agencies are, they are certainly less so than life-tenured federal judges. And the cumulative effect of presidential appointments that arise from several consecutive presidential administrations enhances the likelihood that judicial constructions of statutes will more closely track median electoral preferences than agency interpretations, whether executive or independent.

As a result, whereas Chevron deference is likely to produce predictable political dissatisfaction, Skidmore deference is more likely to align with median electoral political satisfaction. ${ }^{69}$ Contrary to Elhauge's analysis, this analysis might suggest that Chevron is mistaken, but that is by no means a necessary implication. The issue is not whether Chevron is right or wrong; rather it is what trade-off the choice between Chevron and Skidmore reveals.

As stated above, I believe that the critical payoff of Chevron is raising the stakes of political outcomes. In a Chevron regime, political outcomes matter a lot as they will result in potentially broad pendulum swings in agency policy that the judiciary is generally required to respect. If, by contrast, judicial interpretation is closer to the median, and if judicial interpretations of statutes were instead durable, then political outcomes matter far less. Skidmore placed the burden of interpreting ambiguous federal statutes on the federal judiciary, and along with that, diminished the political stakes of this important interpretive process. Chevron placed the burden on relatively more politically sensitive agencies, thereby raising the political stakes of this process. The raised stakes, however, might not have been designed to improve satisfaction by rendering the agency outcomes less relevant, but rather might have been designed to enhance political dissatisfaction by rendering such outcomes—and with them the outcomes of elections-more relevant. $^{70}$

\footnotetext{
${ }^{69}$ Skidmore deference is the pre-Chevron deference standard under which federal courts afforded agencies deference based upon the persuasiveness of the adopted position. Skidmore v. Swift \& Co., 323 U.S. 134, 140 (1944) (holding that agency decisions will be weighed by a court depending on "all those factors which give it the power to persuade, if lacking power to control”).

70 The analysis might also help to explain the resistance of federal judges to the call by various scholars, including Jonathan Macey, see supra note 59, to construe statutes in a manner that minimizes interest group payoffs. Just as there is an inevitable tradeoff between the cost of precedent and its durability, so too there is an inevitable tradeoff between limiting interest group incentives to participate in legislative procurement, which is often the price of doing business, and the successful procurement of desired public interest laws. For a related analysis, see Maxwell L. Stearns, The Public Choice Case Against the Item Veto, 49 WASH. AND LEE L. REV. 385 (1992).
} 
And yet, while Chevron invites potentially broader policy swings over the meaning of statutes than Skidmore, the resulting cheaper-to-obtain political benefits are also shorter lived. The judicial construction of statutes yields an even stronger stare decisis norm than the judicial construction of open-ended constitutional provisions. ${ }^{71}$ Statutory amending would have a more lasting effect precisely because of the greater difficulty in obtaining it. By contrast, an agency victory is fleeting precisely because it is purchased on the cheap, at least in relative terms.

\section{Casey, the Cost of Precedent, and Stare Decisis Revisited}

Let us now return to the question of durability of constitutional precedent. Consider the famous passage from the jointly authored plurality opinion in Planned Parenthood of Southeastern Pennsylvania v. Casey, ${ }^{72}$ which described the attributes of durable constitutional precedent. The plurality stated:

So in this case we may inquire whether Roe's central rule has been found unworkable; whether the rule's limitation on state power could be removed without serious inequity to those who have relied upon it or significant damage to the stability of the society governed by it; whether the law's growth in the intervening years has left Roe's central rule a doctrinal anachronism discounted by society; and whether Roe's premises of fact have so far changed in the ensuing two decades as to render its central holding somehow irrelevant or unjustifiable in dealing with the issue it addressed. ${ }^{73}$

The joint authors thus identified four conditions that must be weighed to ascertain whether a precedent — especially one of the magnitude of Roe — warrants overruling: (1) whether the rule proves unworkable; (2) whether overruling would undermine important reliance interests; (3) whether the subsequent history has so eroded the precedent as to render it an anachronism or hollow shell; and (4) whether the factual premises have been reconceived to the point that the solution now appears irrelevant or unjustifiable. For this analysis, the last two conditions prove most important: the effect of subsequent rulings on the status of the precedent and the later understanding of the precedent's factual premises. In fact, the plurality treats these two formulations as part of a common inquiry by comparing the ongoing vitality of Roe with the diminished vitality — largely owing, in the plurality analysis, to the problem of faulty premisesof Plessy and Lochner. ${ }^{74}$

In the Casey plurality framing, the stare decisis inquiry is forward-looking. It focuses on whether the precedent the Court is called upon to retrench —in that case Roe-has been subsequently eroded. In the series of cases from Plessy to Brown and from Lochner to West

\footnotetext{
${ }^{71}$ See supra note 67 , and accompanying text.

72505 U.S. 833 (1992).

${ }^{73} \mathrm{Id}$. at 855.

${ }^{74}$ Lochner relied upon the Fourteenth Amendment Due Process clause to strike down a federal maximum hour law for bakers, reasoning that the law interfered with the rights of employers and employees to contract for working conditions on mutually acceptable terms and that bakers were not uniquely in need of state legislative protection. Lochner v. New York, 198 U.S. 45 (1905).
} 
Coast Hotel, ${ }^{75}$ the Casey plurality reasoned, the Court had eroded the earlier precedent by exposing the flawed factual foundations on which the earlier precedents rested. Later cases continued to cut back on the original precedents in a manner that eventually rendered the landmark cases subject to overruling hollow shells.

The Casey plurality went on to compare this analysis with the post-Griswold sequence, which had not only failed to erode the personal right of sexual privacy, but had extended it into other realms, including but not limited to the abortion right declared in Roe. Indeed, the Court reasoned, the decisional aspect of privacy—as a variant of the protection against the physical intrusion into sexual privacy — could be viewed as part of an ongoing extension of autonomy, or as sui generis, but either way, there was no evident erosion in the later case history.

This Casey plurality analysis has come under criticism for, among other reasons, claiming to rely on eroded factual foundations despite historical evidence that the foundations had not changed; rather, the normative premises in viewing them had changed. Later cases demonstrated the failure of the Plessy Court to appreciate that "separate but equal" imposed serious costs, psychological and otherwise, on blacks. And the Lochner regime failed to appreciate that laissezfaire had winners and losers. (As if regulatory regimes have only winners!) Moreover, there was clear evidence of such contrary understanding concerning the foundations of Plessy and Lochner at the time of the original decisions. Consider, for example, Harlan's dissent in Plessy and Holmes's dissent in Lochner, both of which characterized the foundations of these decisions in a manner vindicated in the later Supreme Court overrulings. ${ }^{76}$

The Casey joint authors' justification for affording Roe durable precedential status looks forward from Roe itself. What happened since Roe was announced? Was it eroded or did later cases preserve its integrity? Is it a relic, or is it an ongoing part of a larger body of precedent? The joint authors' perspective on the subsequent history of Lochner follows a similar analysis. Certainly there is value in these inquiries. But I would suggest that the private-rights adjudicatory analysis reveals an equal or greater value in a backward-looking precedential analysis.

In a backward-looking analysis, the durability of precedent correlates in large measure with the burden of obtaining it. The more costly a precedent is to obtain, holding all else constant, the more entitled that precedent is to respect. In addition to considering why Plessy and Lochner warranted overruling based on later judicial decisions, focus on why Brown and West Coast

\footnotetext{
${ }^{75}$ West Coast Hotel rejected a Fourteenth Amendment Due Process challenge to a minimum wage law affecting women, thus overturning Adkins v. Children's Hospital, 261 U.S. 525 (1923), and signaling an end to the era of substantive economic due process associated with Lochner. West Coast Hotel v. Parrish, 300 U.S. 379 (1937).

${ }^{76}$ In addition, as Chief Justice Rehnquist observes in his separate opinion, the Casey plurality fumbles over two of its own overrulings, City of Akron v. Akron Center for Reproductive Health, Inc., 462 U.S. 416 (1983), and Thornburgh v. American College of Obstetricians and Gynecologists, 476 U.S. 747 (1986), with no real effort to reconcile them with its own stare decisis analysis. See Casey, 505 U.S. at 948 (Rehnquist, C.J., concurring in part and dissenting in part). The point here, however, is not to quibble with the application of the Casey stare decisis analysis, but rather to challenge the direction of the theory on which it rests.
} 
Hotel deserve respect based on the heavy burden - a burden driven by the need for actual litigants with actual claims - required to bring those precedents about. In each case, the necessary overrulings to obtain these results_of Plessy and Lochner respectively-did not come about overnight. A change in Court personnel-one more favorable to the jurisprudence of Brown and West Coast Hotel -in and of itself was insufficient to force the doctrinal change. Instead, both of these eventual precedents were extremely costly to obtain. They were each the product of a series of cases, separately laying a small piece of the foundation for the eventual result. And even a single disruption in the path, for reasons well beyond the control of the groups motivated to bring about doctrinal change, could produce a substantial delay or even denial of the desired constitutional precedent.

Thus, the painstaking and gradual erosion of the relevant precedents, Plessy and Lochner, followed from cases with actual litigants presenting claims with stakes framed in traditional terms. Although these cases predated the constitutionalizing of standing, they reflect something intuitive about the relationship between the process of judicial decisionmaking and the durability of resulting precedent. Requiring cases to meet traditional adjudicatory criteria, as the Lloyd Gaines story and Poe v. Ullman illustrate, unquestionably raises the cost of obtaining soughtafter precedent. At the same time, however, it raises the value of the results obtained. This is not to suggest that subsequent erosion is unimportant. Indeed, the gradual erosion in other doctrinal contexts beside Brown and Roe ${ }^{77}$ might someday prove to be the foundation for respecting laterobtained precedents.

The very difficulty of obtaining these precedents, and of the gradual erosion of those that came before, enhances the normative justification for durable constitutional precedent. More costly precedent is more durable, and the reverse is also true. Precedent purchased on the cheap, like agency construction of ambiguous statutory provisions, is necessarily worth less. The burdens of meeting traditional justiciability criteria-ripeness, mootness, and standing-certainly made the eventual path from Plessy to Brown and from Lochner to West Coast Hotel more costly. But it also made the eventual precedents obtained far more worthy of respect.

\section{Conclusion}

Public-rights theorists assume that lower cost constitutional rulings will not result in lower value precedent. This chapter demonstrates why that assumption is mistaken. The issue is not the merit of particular matters of constitutional doctrine. Rather, it is about the process through which desired doctrine is obtained.

\footnotetext{
${ }^{77}$ One might argue that because Roe followed an exception to mootnesss_ capable of repetition yet evading review - that signals low-cost precedent. Assuming, however, that there is validity to the Court's assumption that the duration of pregnancy — nine months — is too short for ordinary channels of litigation to resolve a case raising the issue whether there is a Fourteenth Amendment Due Process right to terminate an unwanted pregnancy, then this particular exception appears justified, and the larger analysis, focusing on the line of cases from Griswold to Eisenstadt to Roe demonstrates that the precedent was obtained at high (or at least relatively high) cost.
} 
Those favoring relaxed justiciability to obtain desired public law precedent should recognize an inevitable tradeoff: They can obtain lower-priced/lower-valued goods or higher-priced/highervalued goods. What they cannot obtain is lower-priced/higher-valued goods. The reason is simple. If a change in judicial personnel is a sufficient normative justification for revisiting a question of law, that will also be true when those on the other side experience a favorable change benefitting them. Although arising in a regulatory context, this is also a core lesson of Chevron.

Constitutional precedent should be more durable than agency interpretations of ambiguous statutes subject to Chevron deference. But for that to happen, it should also be more costly. 